\title{
EFFECTS OF INTEREST RATE DEREGULATION ON AGRICULTURAL FINANCE AND GROWTH IN NIGERIA
}

\author{
Louis O. ONYISHI ${ }^{1}$, Chukwuemeka J. ARENE ${ }^{2}$, Chikaosolu M. IFIORAH $*^{3}$
}

\begin{abstract}
Address:
${ }^{1}$ University of Nigeria Nsukka, Faculty of Agriculture, Department of Agricultural Economics, Enugu State, Nigeria ${ }^{2}$ University of Nigeria Nsukka, Faculty of Agriculture, Department of Agricultural Economics, Enugu State, Nigeria

${ }^{3}$ University of Nigeria Nsukka, Faculty of Agriculture, Department of Agricultural Economics, Enugu State, Nigeria *Corresponding Author; e-mail: ifiorahmaryqueen@yahoo.com
\end{abstract}

\begin{abstract}
The study examined the effects of interest rate deregulation on agricultural finance and growth in Nigeria. The study specifically ascertained the factors that determine the aggregate credit volume to agriculture within the periods of regulation and deregulation in the Nigerian economy, determined the effects of government finance interventions on agricultural sector performance in the Nigerian economy, determined the periodic effects of macroeconomic financial indicators on Agriculture's gross domestic product (GDP) contribution to Nigerian economy and estimated the level of real credit growth of agricultural finance in Nigeria. Descriptive statistics, Ordinary Least Squares (OLS) regression technique and chow test were used for data analysis. The chow test showed that there was a significant differential effect on the aggregate credit volume to agricultural sector between the regulated and deregulated regimes. Interest rate was an important determinant of aggregate credit volume to the agricultural sector in Nigeria, especially during the deregulated period but monetary authorities should ensure appropriate determination of interest rate level that will break the double-edge effect of interest rates on savers and investors.
\end{abstract}

Keywords: interest rate, deregulation, agricultural finance, growth, government intervention JEL: E43

\section{INTRODUCTION}

One of the most topical issues in Nigeria today is that of agricultural development and its sustainability. Agriculture is important because it provides food and employment for the populace, raw materials for industries, and market for industrial goods. The significance of agriculture resource in bringing about economic growth and sustainable development of a nation cannot be underestimated. Oji-Okoro (2011) is of the opinion that agriculture resource has been an important sector in the Nigerian economy in the past decades, and is still a major sector despite the oil boom. This, in other words, means that the growth rate of the overall economy is to a large extent dependent on the growth rate in agriculture GDP.

The advent of oil in the early 1970s made Nigeria highly dependent on oil revenue, with the performance of the agricultural sector adversely affected over the years. Although agricultural growth rate in the country increased from an average of about 3\% in the 1990s to about $7 \%$ in mid-2000, certain performance indicators such as food security/sufficiency status of Nigerians continued to decline. Anyanwu, et al (2013) observed that agriculture was among the key significant determinants of Nigeria's GDP with clear dominance from 1960 to 1969 . The abrupt decline from 1970 to
1979 resulted in the advent of commercial exploitation of oil resources, which turned the trend against agriculture and its downstream industries. Government's pretense towards agriculture was obvious since real budgetary spending on the sector was a mere $7.7 \%$ against the 23.1\% expenditure on transportation sector alone (Shimada, 1999). The trend was reversed from 1975 to 1985 with a sharp increment from $23.8 \%$ to $38.12 \%$ (Fig. $1)$.

This sharp increment could be attributed to the involvement of government in direct food production, provision of subsidies to small-holder farmers and creation of more commodity boards for various agricultural and food products. Credit flow to agricultural sector, measured by the amount of guaranteed loan that flowed to the sector under the Agricultural Credit Guarantee Scheme Fund (ACGSF) and the total bank credit to the sector could be attributed to this trend (Azih, 2011). Within the intervals of 1990 to 1999, the trend of the sector's contribution to the nation's GDP hovered around $32.55 \%$ to $34.32 \%$ with a growth rate of $4.1 \%$. The relative stable trend could be attributed to the advent of numerous programs of the then administration ranging from the Directorate of Food, Roads and Rural Infrastructure (DIFRRI) that spilled over to the 1990s to the National Agricultural Land Development Authority (NALDA) that spanned the period of 1991 to 1999. The 
advent of democracy in 1999 to 2009 created a renewed commitment to the agricultural sector with initiatives like the presidential initiatives on selected commodities, the 7-point agenda, and the transformation agenda of the present administration. However, the trend, on the average, remained at about $34.96 \%$. This could be explained on the basis of inadequate funding and lack of institutional arrangements for the implementation of the initiatives. However, the initiatives generated interest and production increased but there were no concurrent provisions for storage and processing resulting in large postharvest losses and apathy on the side of the farmers (FGN Vision 20:20, 2009).

Figure 1: Percentage Contribution of Agriculture to GDP (1970-2012)

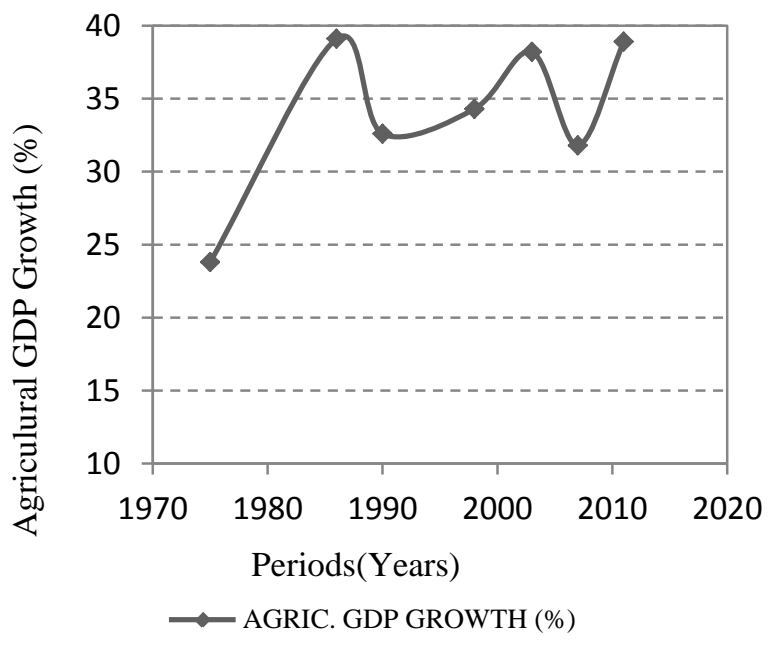

The relationship between financial development and economic growth has been the subject of a growing literature in both developed and developing countries recently (World Bank 2008). To enhance the development of the financial system in the economy, interest rate reform, a policy under the financial sector liberalisation was formulated. The expectation of this reform was that it would encourage domestic savings and make loanable funds available in the banking institutions. Obute, Adyorough and Itodo (2012) defined interest rate deregulation as an economic term used to refer to a situation whereby forces of demand and supply are allowed to determine the value of interest rates rather than its value being administered directly by monetary authorities.

The Agricultural sector, one of the sources of economic growth, has been looked unto to pave the way for economic development because of its potentials. The realization of this fact led the Nigerian government to embark on several agricultural development programmes, many of which, unfortunately failed (Manyong et al. 2005; and Ogungbile 2008). Among these agricultural programmes is the establishment of the Nigerian Agricultural Credit Guarantee Scheme Fund (ACGSF) in 1977 aimed at mobilizing funds from the banking sector for rural development by guaranteeing loans through the commercial banks for investment in agriculture, thereby minimizing the risks involved in financing the sector.
The fluctuations in the financial sector appeared inseparable from the performance of the ACGSF in meeting up with its goals of mobilizing adequate credit for the agricultural sector (Onoja, Onu, and AjodoOhiemi 2012).

Recently the sector had undergone significant changes in terms of the policy environment, number of institutions, ownership structure, depth and breadth of markets, as well as in the regulatory framework. These changes resulted in the mergers and acquisitions in the banking system, which encouraged improvement in the capital base and capacity building of the banks as well as increases in the number of branch network. Although these reforms have been acclaimed to be necessary, it is however debatable if they yielded the anticipated results especially on agricultural lending growth in Nigeria that manifests itself in lending growth rate indicators. These indicators include, increase in the number of farmers that access bank loans, volume of credit to agriculture by banks, equal opportunity of credit accessibility by all classes of farm holders, increase in food security and sustainability, and change of paradigm from land mass based output increase to productivity based output increase. They are expected to facilitate the generation of ideas, define property rights and contracts, stimulate innovation, lower transaction costs and correct government failure. All these would culminate in the reduction of uncertainty and so foster efficiency and enhance strong economic growth (Sanusi 2002).

This study is targeted at the commercial banks that their activities have direct effect on Nigerian economy. We recall that Nigeria banking sector in the recent time has undergone several monetary phases and different policies have been evolved to ensure it does not get worse. All these macroeconomic policies are designed to propel the Nigerian economy to stability, sustainability and self-reliance. Has Nigerian economy attained the above stated objective and to what extent has the government been able to achieve macroeconomic stability through the use the various monetary instruments, as it affects agricultural development and sustainability. Therefore, the question to be addressed in this research is whether financial adjustment policies that include among others, the interest rate deregulation are promoting the required resource inflow to enable agriculture to make its expected contributions to the economy.

The purpose of the study sought to:

i. ascertain the factors that determine the aggregate credit volume to agriculture within the interest regulated and deregulated periods in the Nigerian economy;

ii. determine the effects of government finance interventions on agricultural sector performance in Nigerian economy;

iii. determine the periodic effects of macroeconomic financial indicators on agriculture's GDP contribution to Nigerian economy; and

iv. estimate the level of real growth rate of agricultural financing in Nigeria. 
The following hypotheses we tested in the study:

- factors influencing aggregate credit volume to agriculture sector have no differential effect on both regimes;

- government finance interventions do not affect agricultural sector performance;

- periodic effects of macroeconomic financial indicators do not affect agriculture's GDP contribution.

\section{MATERIAL AND METHODS}

This section highlights the study area, data collection and analytical techniques.

\section{Study Area}

Nigeria is the study area. Nigeria has a total geographical area of 923,768 square kilometres and a population estimate of about 167 million (NBS 2011). The study focused on the agrarian sector, a sector where majority of the Nigerian population is domiciled. Nigeria is located $4^{0} 16^{I}$ and $13^{0} 53^{I}$ north latitudes and $2^{0} 40^{I}$ and $14^{0} 41^{I}$ east longitudes (NBS 2008). The study employed exploratory survey design which covered a period of 42 years made up of 25 years (1970-1986) before the deregulation and 17 years (1987-2011) after the deregulation.

\section{Data Collection}

Secondary data used for the study were computed from CBN Statistical bulletin 2011, CBN annual report 2011, federal budget allocation report, National Bureau of Statistics (NBS) annual reports 2011 and the like. Data collected were annual volume of credit to agricultural sector, average lending rates, volume of savings, inflation rate, and annual government budget allocation to agriculture and so on.

\section{Analytical techniques}

Data were analysed using both inferential and descriptive statistics. Multiple regression model and percentages were the analytical tools used. Further, in order to avoid spurious results emanating from non-stationarity of data series, they will be tested using the Augmented DickerFuller unit root test, Co-integration test and Error Correction Model.

The Augmented Dickey-Fuller unit root test was carried out under the null hypothesis $\mu=0$ against the alternative hypothesis of $\mu \neq 0$. Once a value for the test statistic was computed, it was compared with the relevant critical value for the Dickey Fuller Test (Eq. 1).

$$
A D F_{t}=\frac{\widehat{U}}{S E(\widehat{\mu})}
$$

If the test statistics is greater (in absolute value) than the critical value at $5 \%$ or $1 \%$ level of significance, then the null hypothesis of $\mu=0$ is rejected and no unit root is present. Once this was established, we proceed to test for co-integration.

Co-integration test formula is stated by Eq. 2. $\left(n m \log Y_{A_{t}}, \log A G S G D P_{t}\right)=\propto_{i}+\sum_{i=2}^{p} \propto_{i} n m Z_{t}$

$\left[n m \log Y_{A_{t}}, A G S G D P_{t}-\sum_{i=1} \beta \mathrm{X}_{t-1}\right]+V_{2 t}$

Where:

$\left[n m \log Y_{A_{t}}, \log A G S G D P_{t}-\sum_{i=1} \beta \mathrm{X}_{t-1}\right]$

is the linear combination of the co-integration vectors;

$\mathrm{X}$ is a vector of the co-integrated variables.

Because Eq. (1) is true, the individual influence of the co-integrated variables cannot be separated unless with a correction mechanism through an error correction model (ECM).

The Error Correction Model is expressed by Eq. 3.

$\left(n m \log Y_{A_{t}}, \log A G S G D P_{t}\right)=\propto_{1}+\sum_{i=2}^{\rho} \propto_{i} n m Z_{t}-$ $\left(\lambda E C M_{t-i}\right)+V_{2 t}$

Where: ECM is the Error Correction Model;

$\lambda$ is the magnitude of error corrected, each period specified in its a priori form so as to restore $\eta m \log Y_{A t}$, $\log A G S G D P_{\mathrm{t}}$ to equilibrium.

To ascertain factors that determine the aggregate credit volume to agriculture within the interest regulated and deregulated periods in the Nigerian economy we applied multiple regression model (Eq. 4).

$A_{C V A S_{t}}=b_{0}+b_{1} A I L_{t}+b_{2} A I S_{t}+b_{3} S F I_{t}+b_{4} A I R_{t}+$ $b_{5} R B B_{t}+b_{6} G B A_{t}+b_{7} C P S_{t}+b_{8} F D I_{t}+b_{9} A E R_{t}+e_{t}$

Where:

ACVAS Aggregate credit volume to agricultural sector in time $\mathrm{t}(\mathrm{N})$;

AIL Average interest lending rate in time t (ratio/\%);

AIS Average interest savings rate in time t (ratio/\%);

SFI Savings mobilized by financial institutions in time $t$ $(\mathrm{N})$;

AIR Average Inflation rate in time t (ratio/\%);

RBB Number of rural bank branches in time t;

GBA Government budget allocation to agriculture in time $\mathrm{t}(\mathrm{N})$;

CPS Credit to private sector (agric. \& non agric) in time t (N);

FDI Direct investment into Nigeria's economy in time t $(\mathrm{N})$;

AER Average Exchange rate in time (ratio/\%);

$\mathrm{b}_{\mathrm{o}}$ Interception point;

$b_{1}, b_{2}, b_{3}, b_{4} \ldots b_{9}$ Coefficients of the variables;

t time in year $(1,2,3,4 \ldots t)$;

$\mathrm{e}_{\mathrm{t}}$ error term in time $\mathrm{t}$.

Chow test of significance (F-test) is used to test for the difference in the coefficients between two estimated equations (Chow, 1960) (Eq.5, Eq. 6).

$$
\begin{gathered}
C V_{r}=\Phi_{0}+\Phi_{1} A I L_{t}+\Phi_{2} A I S_{t}+\Phi_{3} S F I_{t}+\Phi_{4} A I R_{t}+ \\
\Phi_{5} R B B_{t}+\Phi_{6} G B A_{t}+\Phi_{7} C P S_{t}+\Phi_{8} F D I_{t}+\Phi_{9} A E R_{t}+ \\
e_{t} \\
\begin{aligned}
C V_{d r}=\beta_{0}+\beta_{1} A I L_{t}+\beta_{2} A I S_{t}+\beta_{3} S F I_{t}+\beta_{4} A I R_{t} \\
+ \\
+\beta_{5} R B B_{t}+\beta_{6} G B A_{t}+\beta_{7} C P S_{t} \\
+\beta_{8} F D I_{t}+\beta_{9} A E R_{t}+e_{t}
\end{aligned}
\end{gathered}
$$


Where:

$\mathrm{CV}_{\mathrm{r}}$ and $\mathrm{CV}_{\mathrm{dr}}$ credit volume to agriculture during the period of regulation and deregulation.

In our studya F-test was expressed by Eq.7.

$$
\mathrm{F}^{*}=\frac{\mathrm{RSS}_{\mathrm{p}}-\mathrm{RSS} 1-\mathrm{RSS} 2 / \mathrm{K}}{\mathrm{RSS} 1+\mathrm{RSS} 2 /(\mathrm{n} 1+\mathrm{n} 2-2 \mathrm{~K})}
$$

Where:

RSSp the residual sum of square for the pooled data; RSS1 the residual sum of square for the regression model for credit agriculture in the period of regulation; RSS2 the residual sum of square for the regression model for credit agriculture in the period of deregulation; $\mathrm{n}_{1} \& \mathrm{n}_{2}$ are number of observations in each model; $\mathrm{K}$ total number of parameters (b’s).

To determine the effects of government finance interventions on agricultural sector performance in Nigerian economy, the study used the multiple regression model (Eq. 8).

$A G S G D P_{t}=Z_{0}+\left(Z_{1} V A C_{t}+Z_{2} V A S_{t}+Z_{3} V S S_{t}+\right.$

$\left.Z_{4} V L S_{t}\right)+e_{t}$

Where:

AGSGDP $_{\mathrm{t}}$ Agricultural sector contribution to gross domestic product in time t;

VAC Volume of credit to agriculture from Agricultural Credit Guarantee Scheme Fund in time t;

VAS Volume of credit to agriculture from Commercial Agricultural Credit Scheme in time t;

VSS Volume of credit to agriculture from Agricultural Credit Support Scheme in time t;

VLS Volume of credit to agriculture from Large Scale Agricultural Credit Scheme in time t;

$\mathrm{Z}_{0}$ Interception point;

$\mathrm{Z}_{1}, \mathrm{Z}_{2}, \mathrm{Z}_{3}, \mathrm{Z}_{4}$ Coefficients of the variables;

e Error term.

The multiple regression model suggested for this study (Eq.9) was used to determine the periodic effects of macroeconomic financial indicators on agriculture's GDP contribution to Nigerian economy.

$$
\begin{aligned}
& A G S G D P_{t}=\propto+\beta_{0} L I_{t}+\beta_{1} I R_{t-1}+\beta_{2} E R_{t-2}+\cdots+ \\
& \beta_{k} S I_{t-k}+U_{t}
\end{aligned}
$$$$
\text { Where: }
$$

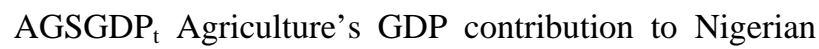
economy;

$\alpha$ Constant or point of intercept;

$\beta_{0}, \quad \beta_{1}, \quad \beta_{2}, . . \quad \beta_{\mathrm{k}}$ The lags (that is multipliers at short/medium/long terms);

$\mathrm{LI}_{\mathrm{t}}, \mathrm{IR}_{\mathrm{t}-1}, \mathrm{ER}_{\mathrm{t}-2}, \mathrm{SI}_{\mathrm{t}-\mathrm{k}}$ The variables (loan interest rate, inflation rate, exchange rate, and savings interest rate);

$\mathrm{t}, \mathrm{t}-1, \mathrm{t}-2$, $\mathrm{t}-\mathrm{k}$ The respective period between 1970 and 2011;

$\mathrm{U}_{\mathrm{t}}$ Error term.

A real credit growth rate model (Eq.10) modified from the study of Sa (2007) was used to estimate the level of real growth rate of agricultural finance in Nigeria.

$$
\mathrm{P}_{t}=100\left[\frac{\frac{C_{t}}{C_{t-1}}}{1+\pi t}-1\right]
$$

Where,

$\pi t$ denotes the inflation rate of a country in time $\mathrm{t}$ $\mathrm{C}_{\mathrm{t}-1}$ is the volume of loan in time $\mathrm{t}-1$.

\section{RESULTS AND DISCUSSION}

This section presents the results and discussion.

To confirm the stationarity status of the data series that entered the models, an Augmented Dickey-Fuller (ADF) unit root test was carried out. If the dependent variable associated to the model is found to be integrated of the same order with the explanatory variables, then linear combination is suspected among the variables (Ucak, Ozturk and Sarac, 2012).

The unit root test was carried out under the null hypothesis $\mathrm{Y}=0$ against the alternative of $\mathrm{Y}<0$. The variables were stationary at first differencing (Table 1). This was deduced from the fact that ADF test statistic of each variable is greater than the critical value of ADF statistic in absolute values at $10 \%$ and $5 \%$ levels. Therefore, the null hypothesis of $\mathrm{Y}=0$ is rejected and no unit root is present. This then permitted for further analysis of the time series data.

Table 1: Augmented Dickey-Fuller Unit root test results First Difference

\begin{tabular}{lrrr} 
Variables & ADF & $5 \%$ & $10 \%$ \\
\hline Aggregate credit volume AVCAS $_{\mathrm{t}}$ & -4.47 & -3.52 & -2.92 \\
Average interest lending rate $\mathrm{AIL}_{\mathrm{t}}$ & -4.98 & -3.52 & -2.92 \\
Average interest savings rate $\mathrm{AIS}_{\mathrm{t}}$ & -4.87 & -3.52 & -2.92 \\
Savings mobilized by $_{\text {financial institutions SFI }}$ & -4.50 & -3.52 & -2.92 \\
Average Inflation rate AIR $_{\mathrm{t}}$ & -7.12 & -3.52 & -2.92 \\
Number of rural bank branches $\mathrm{RBB}_{\mathrm{t}}$ & -4.28 & -3.52 & -2.92 \\
Government budget allocation GBA $_{\mathrm{t}}$ & -4.55 & -3.52 & -2.92 \\
Credit to private sector CPS $_{\mathrm{t}}$ & -4.15 & -3.52 & -2.92 \\
Direct investment FDI $_{\mathrm{t}}$ & -6.13 & -3.52 & -2.92 \\
Average Exchange rate AER & -7.17 & -3.52 & -2.92
\end{tabular}

Source: Computed from CBN statistical bulletin 2011, CBN annual report 2011, NBS annual report 2011 and Federal budget allocation report for various years $(1970-2011)$

Determinants of aggregate credit volume to agricultural sector during the regulated and deregulated regimes in Nigeria

The factors that determine the aggregate credit volume to agricultural sector during the regulated and deregulated periods in Nigeria were ascertained using a multiple regression model.

By estimated multiple regression analysis, about $61 \%$ and $71 \%$ of the total variance on the aggregate credit volume to agriculture before and during deregulation in Nigeria was explained by joint action of some explanatory variables that were included in the model (Table 2, Table 3). The remaining 39\% and 29\% unexplained during the period of regulated and deregulated regimes respectively were due to the random variable (u). 
Table 2: Determinants of aggregate credit volume to agricultural sector during regulation regime

\begin{tabular}{|c|c|c|c|c|}
\hline Variables & Coefficients & Standard Error & t-values & Sig. level \\
\hline Constant & 2207.6 & 2185.5 & 1.01 & $0.00^{* * *}$ \\
\hline Aggregate credit volume AVCAS & 17.50 & 1381.13 & 0.01 & 0.73 \\
\hline Aver. interest lending rate AIL & 1318.90 & 3412.84 & 0.38 & $0.08 *$ \\
\hline Aver. interest savings rate AIS & 28.90 & 2124.22 & 0.01 & 0.97 \\
\hline Savings mobilized by financial institutions SFI & -75.42 & 382.82 & -0.19 & $0.00 * * *$ \\
\hline Average Inflation rate AIR & 1283.92 & 2657.52 & 0.48 & 0.63 \\
\hline Number of rural bank branches RBB & 128.20 & 388.27 & 0.33 & $0.02 * *$ \\
\hline Government budget allocation GBA & 2482.18 & 1693.95 & 1.46 & 0.88 \\
\hline Credit to private sector CPS & 402.77 & 698.28 & 0.57 & 0.74 \\
\hline Direct investment FDI & 162.74 & 941.34 & 0.17 & 0.85 \\
\hline \multicolumn{5}{|l|}{$\mathrm{R}^{2}=0.61$} \\
\hline \multicolumn{5}{|l|}{ Adjusted $\mathrm{R}^{2}=0.43$} \\
\hline F-statistics = 18.51 & & & & \\
\hline
\end{tabular}

Table 3: Determinants of aggregate credit volume to agricultural sector during the deregulation period

\begin{tabular}{lrrrl}
\hline Variables & Coefficients & Standard Error & t-values & Sig. level \\
\hline Constant & 6774.34 & 18208344 & 0.00 & 0.02 \\
Aver. interest lending rate AIL & 810.17 & 420.16 & 1.92 & $0.04^{* *}$ \\
Aver. interest savings rate AIS & 435.54 & 359.81 & 1.21 & $0.05^{* *}$ \\
Savings mobilized by financial institutions SFI & 101.97 & 624.44 & 0.16 & $0.04^{* *}$ \\
Average Inflation rate AIR & -82.00 & -154.38 & 0.53 & $0.08^{*}$ \\
Number of rural bank branches RBB & 1868.67 & 6576.08 & 0.25 & $0.08^{*}$ \\
Government budget allocation GBA & 101.51 & 96.40 & 1.08 & 0.53 \\
Credit to private sector CPS & 234.96 & 650.40 & 0.36 & $0.04^{* *}$ \\
Direct investment FDI & 70.03 & 307.85 & 0.22 & 0.34 \\
Aver. interest lending rate AIL & 810.17 & 420.16 & 1.92 & 0.72
\end{tabular}

$\mathrm{R}^{2}=0.71$

Adjusted $\mathrm{R}^{2}=0.63$

F-statistics $=13.83$

Note: $* * *, * *$ and $*$ represent significance at $1 \%, 5 \%$ and $10 \%$

Source: Computed from CBN statistical bulletin 2011, CBN annual report 2011, NBS annual report 2011 and Federal budget allocation report for various years $(1970-2011)$

Table 4: Effects of government finance intervention on agricultural sector performance in Nigerian economy

\begin{tabular}{|c|c|c|c|c|}
\hline Variables & Coefficients & Standard Errors & t-values & Sig. level \\
\hline $\begin{array}{l}\text { Volume of credit to agriculture } \\
\text { from Agricultural Credit Guarantee Scheme Fund VAC }\end{array}$ & 2.11 & 1.08 & 1.95 & $0.00 * * *$ \\
\hline $\begin{array}{l}\text { Volume of credit to agriculture } \\
\text { from Commercial Agricultural Credit Scheme VAS }\end{array}$ & 0.05 & 0.09 & 0.5 & $0.02 * *$ \\
\hline $\begin{array}{l}\text { Volume of credit to agriculture } \\
\text { from Agricultural Credit Support Scheme VSS }\end{array}$ & -0.07 & 0.13 & -0.53 & 0.73 \\
\hline $\begin{array}{l}\text { Volume of credit to agriculture } \\
\text { from Large Scale Agricultural Credit Scheme VLS } \\
\mathrm{R}^{2}=0.51 \\
\text { Adjusted } \mathrm{R}^{2}=0.44 \\
\text { F-statistics }=7.58\end{array}$ & -0.15 & 0.14 & -1.07 & 0.91 \\
\hline
\end{tabular}


Average lending interest rate was positively signed in both regimes (regulated and deregulated), but statistically significant at $5 \%$ during the period of deregulation. This means that the removal of subsidies on interest rate has impacted positively on GDP.

Also, the average exchange rate was positive and statistically significant during the deregulated regime showing that the higher the exchange rate, the higher the GDP.

Effects of government finance interventions on agricultural sector performance in Nigerian economy

To determine the effects of government finance interventions on agricultural sector performance in Nigerian economy, variables obtained from four government programmes were analysed using multiple regression model.

Results showed that about $51 \%$ of the total variation in agricultural sector performance was explained by variations in the explanatory variables used in the model. Volume of credit to agriculture from Agricultural Credit Guarantee Scheme Fund and volume of credit to agriculture from Commercial Agricultural Credit Scheme were in line with the a priori expectation (Table 4). This indicated that volume of credit to agriculture from Agricultural Credit Guarantee Scheme Fund (ACGSF) is a major determinant of the government finance interventions on agricultural sector and its contribution to GDP of Nigerian economy. It also implied that the larger the volume of credit by Agricultural Credit Guarantee Scheme Fund, the higher the level of agriculture sector contribution to Nigeria's GDP. This therefore means that the financial intervention from these agencies has impacted positively on farmers' welfare, especially the small-holder farmer majority as revealed by the increased per capita agriculture GDP.

The coefficient of volume of credit to agriculture from Commercial Agricultural Credit Scheme (CACS) was positive while those of volume of credit to agriculture from Agricultural Credit Support Scheme (ACSS) and volume of credit to agriculture from Large Scale Agricultural Credit Scheme (LSACS) were negative though none of the variables were statistically significant. The a priori expectations were also not met. This implied that volume of credit to agriculture from Commercial Agricultural Credit Scheme, volume of credit to agriculture from Agricultural Credit Support Scheme and volume of credit to agriculture from Large Scale Agricultural Credit Scheme though relevant in the Nigerian government finance interventions on agricultural sector, might not have been funded reasonably enough to make any impact on agricultural financing.

The periodic effects of macroeconomic financial indicators on agricultural GDP contribution to the Nigerian economy

In determining the periodic effects of macroeconomic financial indicators on agricultural GDP contribution to the Nigeria economy, the short, medium and long run periods were analysed.

The multiplier effects (lags) of the macroeconomic financial indicators implied that annual average loan interest rate, and exchange rate affected the agriculture's GDP contribution at short, medium and long run periods, while annual average savings interest rate had short and long run multiplier effects on the agriculture's GDP contributions to Nigerian economy (Table 5). The inflation rate had no multiplier effect on the agriculture's GDP contribution within the period under study.

The annual average loan interest rate showed negative coefficient in the short run and positive coefficients in the medium and long run periods but all coefficients were statistically significant.

The coefficient of annual average savings interest rate was positive at the short run and was statistically significant of $1 \%$ level, negative coefficient at the long run and was statistically significant at 5\% level. This indicated that current savings interest rate affected the agricultural output production and agricultural GDP contribution within the short run and long run periods but negatively due to some changes in macroeconomic financial policies overtime. At short and long run, the exchange rate showed positive coefficient and statistical significance at $5 \%$ and $1 \%$ level respectively, while at medium run, it showed negative coefficient. This indicated that there existed relationship between exchange rate and agricultural GDP contribution to Nigerian economy at short and long run periods indicating that the exchange rate policy would encourage high activities in agricultural sector with particular reference to agro-exports. This result conformed to the findings of Abiodun and Salau (2010) who revealed that real exchange rate jointly explained the variation in the Nigeria aggregate agricultural output in the short and long run.

\section{The level of real growth rate of agricultural financing in Nigeria (1970-2011)}

The real growth rate takes into account the inflation rate at a given time and this study has taken this into account to estimate the level of real growth rate of agricultural finance in Nigeria.

By estimates, agricultural credit growth rate increased in real terms at $0.01 \%$ under the period of study (Table 6).

Also, agricultural credit boom in Nigeria was found to be negative $(-24.57 \%)$ within the period under review. This indicated that financial institutions (Banks) were not much concerned with the financing of economic production sectors like agriculture.

The F-test (18.518) was greater than the F-tabulated value (7.012) at $5 \%$ level of probability. Therefore the factors influencing aggregate credit volume to agricultural sector have significant differential effect on both the regulated and deregulated regimes. 
Table 5: Periodic effects of macroeconomic financial indicators on agricultural contribution to Nigerian economy

\begin{tabular}{lrrrc}
\hline Variable & Coefficient & Std. Error & t-ratio & p-value \\
\hline Constant & -226544 & 77961 & -2.90 & $0.01 * * *$ \\
Annual_Average_Loan_Interest_1 & -32891.8 & 7315.44 & -4.49 & $0.00 * * *$ \\
Annual_Average_Loan_Interest_2 & 29802.9 & 6597.39 & 4.51 & $0.00 * * *$ \\
Annual_Average_Loan_Interest_3 & 37676.9 & 9377.59 & 4.01 & $0.00 * * *$ \\
Annual_Average_Savings_Interest_1 & 60004.8 & 14908.7 & 4.02 & $0.00 * * *$ \\
Annual_Average_Savings_Interest_2 & -26928.3 & 15618.3 & -1.72 & 0.10 \\
Annual_Average_Savings_Interest_3 & -53763.7 & 20955.9 & -2.56 & $0.01 * *$ \\
Annual_Average_Exchange_Rate_1 & 6222.29 & 2829.53 & 2.19 & $0.03 * *$ \\
Annual_Average_Exchange_Rate_2 & -19396.8 & 2767.72 & -7.00 & $0.00 * * *$ \\
Annual_Average_Exchange_Rate_3 & 27860.3 & 2075.6 & 13.42 & $0.00 * * *$ \\
Annual_Average_Inflation_Rate_1 & -7.72654 & 2186.35 & -0.00 & 0.99 \\
Annual_Average_Inflation_Rate_2 & -816.349 & 1902.13 & -0.42 & 0.67 \\
Annual_Average_Inflation_Rate_3 & -3426.65 & 2550.48 & -1.34 & 0.19 \\
Agricultural_s_GDP_contribution_1 & 1.02031 & 0.069 & 14.73 & $0.00 * * *$ \\
Agricultural_s_GDP_contribution_2 & 0.00326591 & 0.087 & 0.03 & 0.97 \\
Agricultural_s_GDP_contribution_3 & 0.0593839 & 0.086 & 0.68 & 0.49 \\
u(-3) & -3.60104 & 0.169 & -21.21 & $0.00 * * *$ \\
Statistics based on the rho-differenced data: & & & \\
Mean dependent var & 19453412 & & S.D. dependent var & 33113221 \\
Sum squared resid & $2.89 \mathrm{e}+12$ & & S.E. of regression & 380275.7 \\
R-squared & 0.999207 & & Adjusted R-squared & 0.998612 \\
F(15, 20) & 17690.90 & & P-value(F) \\
Rho & -0.021780 & & Durbin-Watson & $7.45 \mathrm{e}-38$ \\
\hline
\end{tabular}

Note: $* * *$ and $* *$ represent significance at $1 \%$ and $5 \%$

Source: Computed from CBN statistical bulletin 2011, CBN annual report 2011, NBS annual report 2011 and Federal budget allocation report for various years $(1970-2011)$

Table 6: Level of real credit growth rate in agricultural financing in Nigeria (1970-2011)

\begin{tabular}{ll}
\hline Items & Rate \\
\hline Nominal growth rate & $2.11 \%$ \\
Real credit growth rate & $0.01 \%$ \\
Agriculture credit boom & $-24.57 \%$ \\
\hline
\end{tabular}

Source: Computed from CBN statistical bulletin 2011, CBN annual report 2011, NBS annual report 2011 and Federal budget allocation report for various years $(1970-2011)$

\section{CONCLUSION AND RECOMMENDATIONS}

The study examined the effects of interest rate deregulation on agricultural finance and growth in Nigeria from 1970-2011. Theory explaining interest rate deregulation suggests that this phenomenon will promote required resource inflow into agriculture to enable it makes its expected contributions to national development. By testing the hypothesis, the result showed that interest rate deregulation had significant and positive impact on agricultural finance in Nigeria within the period under review. Also, deregulation of interest rates in Nigeria may not optimally achieve its goals, if those factors, which do not meet the a priori expectations on aggregate credit volume to agriculture, are not tackled. Interest rate plays a significant role in enhancing economic activities and high interest rate attracts domestic savings but at the same time it discourages local investors and as such:

- monetary authorities should ensure appropriate determination of interest rate level that will break the double-edge effect of interest rate on savers and investors;
- government should improve macroeconomic indicators such as income level, level of investment, and so on;

- $\quad$ government should lend to agriculture especially to small-scale farmers; and

- government should use necessary incentives to attract more foreign direct investment to agricultural sector.

Acknowledgement: The authors acknowledge, with gratitude, the useful contributions made on the paper by Prof. Bola Okuneye, the National President of the Nigerian Association of Agricultural Economists during the 2014 Annual National Conference of the association held in Niger Delta University, Wilberforce Island, Bayelsa State, Nigeria.

\section{REFERENCES}

ABIODUN, E. O. - SALAU, A. S. (2010). Agricultural Response to Prices and Exchange Rate in Nigeria: Application of Co-integration and Vector Error Correction Model (VECM). Journal of Agri. Sci, 1(2): 73-81. 
http://www.krepublishers.com/02-Journals/JAS/JAS-010-000-10-Web/JAS-01-2-000-10-Abst-PDF/JAS-01-2073-10-022-Obayelu-A-E/JAS-01-2-073-10-022-

Obeyelu-A-E-Tt.pdf

ANYANWU, S.O. - OFFOR, U.S. - ADESOPE, O.M. IBEKWE, U.C. (2013). Structure and Growth of the GDP (1960-2008): Implication for Small and Medium Enterprises in Nigeria. Global Advanced Research Journal of Management and Business Studies, 2(6): 342$348 . \quad$ Retrieved from http://garj.org/garjmbs/pdf/2013/June/Anyanwu\%20et\%2 0al.pdf

AZIH, I. (2011). “A Background Analysis of the Nigerian Agricultural Sector (1998-2007). Oxfam Novib Economic Justice Campaign in Agricuture www.manufacturingtodynigeria.com.

CENTRAL BANK OF NIGERIA (2011). Economic and Financial Review, 48(4).

CENTRAL BANK OF NIGERIA (2011). Statistical bulletin and annual report. Abuja: Central Bank of Nigeria. Retrieved from: http://www.cbn-treasury.gov.ng CHOW, G. C. (1960). Test of Inequality between Sets of Coefficients in two Linear Regressions. Econometrica, 28; 591-605.

FGN (2009). "Report of the Vision 20:20 National Technical Working Group on Agriculture and Food Security”, July.

GUJARATI, D. N. (2006). Essentials of Econometrics. 3rd Ed. McGraw-Hill International: New York.

MANYONG, V. M. - IKPI, A. - OLAYEMI, J. K. YUSUF, S. A. - OMONONA, B. T. - OKORUWA, V. IDACHABA, F. S. (2005). Agriculture in Nigeria: Identifying opportunities for Increased Commercialization and Investment. IITA, Ibadan Nigeria, 159.

MENDOZA, G. E. - TERRONES, M. E. (2008). An Anatomy of Credit Booms: Evidence from Macro Aggregate and Micro Data. FRB International Finance Discussion Paper No. 936. DOI:

http://dx.doi.org/10.2139/ssrn.1292330

NATIONAL BUREAU OF STATISTICS (2008). Annual Abstract of Statistics, National Bureau of Statistics, Abuja Nigeria.
NATIONAL BUREAU OF STATISTICS (2011). Annual Statistical Report of Nigeria, National Bureau of statistics, Abuja Nigeria.

OBUTE, C. - ADYOROUGH, A. - ITODO, A. I. (2012). An Assessment of the Impact of Interest Rate Deregulation on Economic Growth in Nigeria (19642009). Journal of Business and Organizational Development, 4 . Cenresin publications. http://www.cenresinpub.org/pub/September\%20Edition \%202012/JBOD/Page\%2039-57_921_.pdf

OGUNGBILE, A. O. (2008). Poverty reduction and access to agricultural inputs. Government's Seven Point Agenda: Implication for Agricultural Development.

OJI-OKORO, I. (2011). Analysis of the Contribution of Agricultural Sector on the Nigerian Economic Development. World Review of Business Research, 1(1), $191-200$.

ONOJA, A. O. - ONU, M. E. - AJODO-OHIEMI, S. (2012). Contributions of Financial Sector Reforms and Credit Supply to Nigerian Agricultural Sector (19782009). CBN Journal of Applied Statistics, 2(27). Retrieved from: http://www.cenbank.org/

SA, S. (2007). Capital Flows and Credit Booms in Emerging Market Economies. Banque de France, Financial Stability Review, 9, December.

SANUSI, J. O. (2002). The Evolution of Monetary Management in Nigeria and its Impact on Economic Development. CBN Bulletin, 26(1) 1-19.

SHIMADA, S. (1999). A Study of increased Food Production in Nigeria: The Effect of the Structural Adjustment Programme on the Local Level. Graduate School of Asian and African Area Studies, Kyoto University.

UCAK, H. - OZTURK, I. - SARAC, T.B. (2012). Total Factor Productivity and Export Relationship: The Case of Agriculture Sector in Four Mediterranean Countries. Actual Problems of Economics, 9(135), 514-525.

WORLD BANK (2008). Finance For All Policies and Pitfalls in Expanding Access. A World Bank Policy Research Report. The International Bank for Reconstruction and Development / the World Bank: Washington DC. 